\title{
INFLUENCE OF COATING AND TOOL GEOMETRY ON THE TOOL LIFE
}

\author{
BENGA, G. \& CIUPITU, I.
}

Abstract: The paper deals with the influence of coatings on the tool life of the different shapes of taps in a thread cutting process. The PVD procedure was employed in order to apply a TiAlN coating on the various type of taps.The influence of the tap geometry was very important and affected significantly the tool life measured in the number of holes tapped. The wear pattern for each type of tap was analyzed as well.

The TiAlN coatings promote the formation of protective alumina films composed of amorphous-crystalline structures improving the tribological behavior of the coated tools.

Key words: tapping, tap geometry, PVD coatings, tool wear
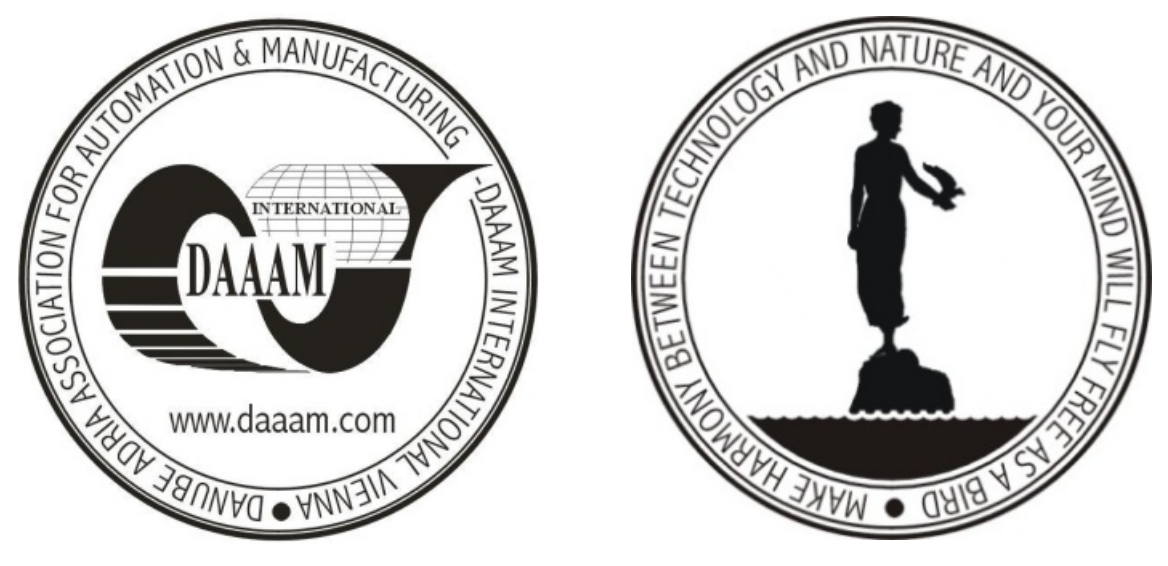

Authors' data: Univ. Prof. Dr. Benga, G[abriel]; Univ. Prof. Dr. Ciupitu, I[on], University of Craiova, Faculty of Engineering and Management of Technological; Systems, Calugareni Street, No.1, 220037, Drobeta Turnu Severin, Mehedinti, Romania gabriel.benga@imst.ro, ion.ciupitu@imst.ro

This Publication has to be referred as: Benga, G[abriel] \& Ciupitu, I[on] (2009). Influence of Coating and Tool Geometry on the Tool Life, Chapter 91 in DAAAM International Scientific Book 2009, pp. 931-938, B. Katalinic (Ed.), Published by DAAAM International, ISBN 978-3-901509-69-8, ISSN 1726-9687, Vienna, Austria DOI: $10.2507 /$ daaam.scibook.2009.91 